DOI 10.18551/rjoas.2019-12.30

\title{
THE EFFECT OF LEADER EXCHANGE ON INNOVATIVE WORK BEHAVIOR THROUGH WORK ENGAGEMENT
}

\author{
Ardianti Pramudita, Handoyo Seger \\ Department of Industrial and Organizational Psychology, Faculty of Psychology, \\ University of Airlangga, Surabaya, Indonesia, \\ ^E-mail: pramuditaardiantii@gmail.com
}

\begin{abstract}
The aim of this study is to find out the effect of Leader member exchange on innovative work behavior trough work engagement of manufacture company employees in Indonesia. This study is conducted 177 employees who work in Manufacture Company. The Sample consisted of 114 men and 63 women. The sampling technique used is a combination of incidental and snowball sampling techniques. Data collection tool consisting of a questionnaire with a Likert scale model consisting of three scales including the scale of the exchange of members of leaders, the scale of work engagement, and the scale of innovative work behavior. The processing data used SEM methods are based on PLS with SmartPLS programs. The result showed there was an effect of leader member exchange on innovative work behavior, with work engagement as a mediator, and the effect categorized as partial mediation.
\end{abstract}

\section{KEY WORDS}

Leader exchange, work engagement, innovative work, behavior.

The level of technological, social, and institutional changes results in shorter life cycles than current products (Dejong, 2007). This condition requires companies to be ready to change permanently, flexibly and feel the business environment to achieve dynamic adaptation to the context of the complexities of the globalization process and unexpected changes (Contreras, et al., 2017). Innovative organizations will find it easier to deal with environmental challenges faster and better than less innovative organizations (Damanpour and Gopalakrishnan, 1998).

The results of the 2018 global innovation index, Indonesia ranked 85th out of 126 countries (The Global Innovation Index 2018). Indonesia's position ranks 14th out of a total of 15 countries for the Southeast Asia, East Asia and Oceania region (The Global Innovation Index 2018). Indonesia's position is also below Malaysia, Thailand, Vietnam, Brunei and the Philippines. The rate of growth in the Indonesian economy has increased 3.09\% compared to 2017 (BPS, 2018). One area that supports economic growth in Indonesia is the growth of manufacturing industry production. The growth of the manufacturing industry increased by $5.04 \%$ from 2017 (BPS, 2019). The manufacturing industry is one area of the company that many need to do a lot of innovation. With an increase in innovation in the industrial sector in Indonesia, especially in the manufacturing industry, it will be able to develop the national economy. The manufacturing industry has a very strategic role in driving Indonesia's economic growth to be even higher and sustainable (Anggita, 2019).

One way for organizations to be more innovative is to encourage the ability of employees to innovate (De Jong, 2007). De Jong (2007) describe innovative work behavior (IWB) as behavior directed towards the initiation and application (within a work role, group or organization) of new and useful ideas, processes, products or procedures. Previous study showed the success of innovative work behavior is influenced by several factors including work engagement (Anwar and Niode, 2017; Kim and Park, 2017; Contreras, 2017 et al., 2017), leader member exchange (Alsughayir, 2017; Ansari, et al., 2018; June and Keng, 2014; Argawal, et al. 2012; and Wang, et al., 2015).

Leader member exchange is the main predictor of work engagement (Dhivya and Sripirabaa, 2015). Research conducted by Dhivya and Sripirabaa (2015) shows that 
employees having the quality of exchange of leader members with their superiors will increase work engagement and employee performance. Research conducted by Tanskanen, et al. (2018) also shows the exchange of leader members has a strong influence on individual performance and employee engagement.

Schaufeli et al (2002) involve work attachment as positive thinking and provide a sense of inner fulfillment, which is related to work characterized by high enthusiasm (enthusiasm), dedication (dedication), and appreciation (absorption). Work engagement not only addresses conditions and specifics, but is more focused on affective and cognitive persistent, not only focused on specific objects, events, individuals, or specific therapies (Schaufeli, et al., 2002). Research conducted by Demerouti, et al (2001) shows work attachment has a positive impact on health and work effects. Employees who have work attachments will influence innovative work behavior (Argawal, 2014; Contreras, et al., 2017). While other studies conducted by Argawal, et al. (2012) shows that work engagement as a mediator is related to the influence of leader member exchange on innovative work behavior.

Agarwal, et al. (2013) shows that direct leadership has an important role in fostering employee engagement. When employees receive support and care from the direct leader, they reciprocate in dedicating efforts to complete the task (Agarwal, et al., 2012). Previous research found the results of work engagement mediate the influence of leader member exchange on innovative work behavior. This study departs from research conducted by Argawal, et al (2012) who examined the relationship between leader member exchange, innovative work behavior, and turnover intentions: mediated by the role of work engagement in the service sector in India. The results of research conducted by Argawal et al (2012) show that leader member exchange influences innovative work behavior with work engagement as a mediator, where the mediating effect is partial or partial.

In this study conducted in the manufacturing sector. The manufacturing industry is one area of companies that many need to do a lot of innovation related to processes, products, or procedures. Organizations must have a competitive advantage in order to survive in the rapidly changing business environment.

\section{LITERATURE REVIEW}

Leader member exchange theory focuses on the quality of interaction between superiors and employees (Graen and Uhl-Bien, 1995). An effective leadership process occurs when leader and employees are able to develop mature leadership relationships where leader perceive subordinates as partners and thus subordinates will get access to utilize this relationship (Graen and Uhl-Bien, 1995). Liden and Maslyn (1998) find individuals who are in high quality will get more interesting tasks and are more in line with what is desired by the boss, more frequent communication frequency with the boss, higher participation and influence and control over team activities, and also receive more support, recognition, rewards and rewards compared to employees who have low quality leader member exchange relationships. Leader member exchange has four dimensions, namely contribution, loyalty, affect, professional respect (Liden and Maslyn (1998).

Schaufeli et al. (2002) defines work engagement as a positive state of mind and provides a sense of inner fulfillment, which is associated with work that is characterized by vigor, dedication, and absorption. Work engagement is not just a momentary and specific condition, but work attachment is more directed towards affective and pervasive cognitive and cognitive conditions, not just focusing on certain objects, events, individuals, or certain behaviors (Schaufeli et al., 2002).

West and Farr (1990, in De Jong and Den Hartog, 2010) define innovative work behavior as an individual's behavior that aims to achieve the initiation and intentional introduction (within a work role, group or organization) of new and useful ideas, processes, products or procedures. Innovative work behavior not only includes making ideas, but also the behavior needed to implement ideas and achieve improvements that will improve personal and / or business performance (De Jong and Den Hartog, 2008). Employees who have innovative work behavior will exhibit two behaviors, namely behavior related to 
creativity and behavior aimed at carrying out ideas and innovation (De Jong and Den Hartog, 2008). De Jong and Den Hartog (2010) divide innovative work behavior into four stages, namely idea exploration, idea generation, championing ideas, and idea implementation.

$\mathrm{H} 1$ : Leader member exchange has a significant positive relationship with innovative work behavior. behavior.

H2: Work engagement has a significant positive relationship with innovative work

H3: Leader member exchange has a significant positive relationship with innovative work behavior mediated by work engagement.

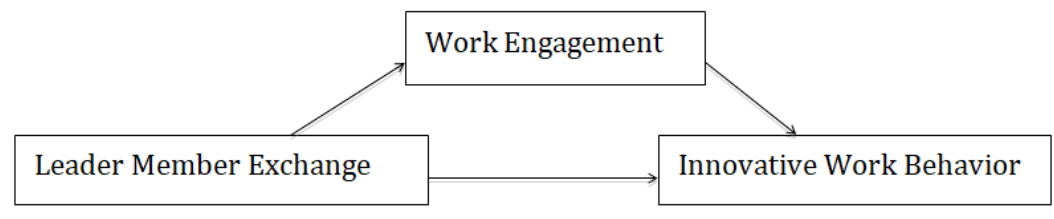

Figure 1 - Conceptual Model

\section{METHODS OF RESEARCH}

We collected data with questionnaires in manufacturing sector. The samples of this study were 177 employees who work in Manufacture Company. The Sample consisted of 114 men and 63 women, the average age was 26-30, the average length of work ranged from 1-5 years. Concerning education, 93 employees held a university degree.

We assessed leader member exchange using scales form 1 (fully disagree) 7 (fully agree) with the twelve items scale developed by Liden and Maslyn (1998). We assessed work engagement using scales form 1 (never) to 7 (very often) with the seventeen items scale Utrecht Work Engagement Scale (UWES) developed by Schaufeli and Bakker (2004). We assessed innovative work behavior using scales form 1 (never) to 5 (very often) with the ten items scale developed by De Jong and Den Hartog (2010). The overall scale exhibited adequate internal consistency (leader member exchange $(\alpha=0.926)$; work engagement $(\alpha=$ $0.936)$; innovative work behavior $(\alpha=0.916)$.

\section{RESULTS AND DISCUSSION}

The data analysis used was Partial Least Square (PLS) to predict the relationship between the constructs and be able to be used as a confirmation theory to build relationship that has not have theoretical foundation or for testing propositions. The purpose of this study is to explain the effect of leader member exchange on innovative work behavior with work engagement as a mediator.

Table 1 - Means, Standard Deviation, and Correlation among Variables

\begin{tabular}{llllll}
\hline & Mean & St. Dev & Adj. R2 & CR & AVE \\
\hline 1.Leader Member Exchange & 59.80 & 12.62 & & 0.929 & 0.523 \\
2.Work Engagement & 92.81 & 13.61 & 0.198 & 0.936 & 0.508 \\
3.Innovative work behavior & 39.45 & 5.86 & 0.455 & 0.908 & 0.531 \\
\hline
\end{tabular}

St. Dev = standard deviation; $A d j$. R2 = adjusted $R$-squared; $C R=$ composite reliability; $A V E=$ average variance extracted.

Table 2 - Model Results

\begin{tabular}{llll}
\hline Variable & T-Statistic & P Values & Comment \\
\hline Direct Effects & & & \\
\hline LMX $\rightarrow$ IWB & 2.89 & 0.004 & Hypothesis 1 supported \\
\hline WE $\rightarrow$ IWB & 9.79 & 0.000 & Hypothesis 2 supported \\
\hline Indirect Effect & & & \\
\hline LMX $\rightarrow$ WE $\rightarrow$ IWB & 4.19 & 0.000 & Hypothesis 3 supported \\
\hline
\end{tabular}

$L M X=$ Leader Member Exchange; WE = Work Engagement; IWB = Innovative Work Behavior. $P<0,05$. 
Leader member exchange is a significant direct positive relation to innovative work behavior $(p=0.004, t=2.89)$, supporting $\mathrm{H} 1$. We found a significant direct positive relation between work engagement and innovative work behavior $(p=0.000, t=9.79)$, supporting $\mathrm{H} 2$. The positive indirect relation and significant between leader member exchange and innovative work behavior via work engagement $(p=0.000, t=4.19)$. Hypothesis 3 was supported. This study using the VAF calculation to determine the magnitude of the mediation effect value by the formula developed by Preacher \& Hayes (Hair, et al., 2014):

Table 3 - FAV Model Results

\begin{tabular}{llll}
\hline $\mathrm{VAF}$ & Formula & Result & Comment \\
\hline $\mathrm{LMX} \rightarrow \mathrm{WE} \rightarrow \mathrm{IWB}$ & $(4.19) /(4.19+2.89)$ & $0.59=59 \%$ & Partial Mediation \\
\hline
\end{tabular}

Variable mediator are categorized as partial mediation if the VAF value ranges from $20-80 \%$, but if the VAF value is less than $20 \%$, it can be concluded that there is almost no mediating effect. The result showed there was an effect of leader member exchange on innovative work behavior, with work engagement as a mediator, and the effect categorized as partial mediation.

Leader member exchange showed positive effect and significant with innovative behavior. The findings of the above study were consistent with previous studies by Alsughayir, (2017); Anshari, et al., (2018); June dan Keng (2014); Argawal, et al. (2012); Wang, et al., (2015). These studies explain that the high quality leader member exchange can influence of innovative work behavior in subordinates. Employees who have a quality leader member exchange will achieve individual innovation, because the employee not only receives more support and resources, but also enjoys a better reputation and higher support in the group (Wang, et al., 2015). High quality leader member exchange will encourage subordinates to be more innovative when doing their work (Alsughayir, 2017). When subordinates have high quality leader member exchange, it will make subordinates more comfortable in suggesting innovative ideas (June and Keng, 2014). Employees who have high quality leader member exchange will have more time with the leader, more guidance information, and more emotional support than employees who have low quality leader member exchange (Volmer et al., 2012).

Work engagement showed positive relation with innovative behavior. The findings of the above study were consistent with previous studies which work engagement has a positive and significant effect on innovative work behavior (Kim and Park, 2017; Park, et al., 2013). Innovative work behavior in individuals depends on how they are attached to their work and how they feel when working (Park et al., 2013). Employees who have work engagement will have positive conditions of mind and provide a sense of inner fulfillment, which is related to work that is characterized by a high spirit of dedication, and appreciation of his work (Schaufeli, et al, 2002). Employees who experience positive emotions when they have an attachment to their work will facilitate these employees to explore, assimilate, share new information and experiences, and apply them (Park, et al., 2013). Employees with a high level of work engagement are more likely to look for new and innovative ideas (Park et al. 2013). In addition, work engagement causes an increase in positive employee behavior, namely innovative work behavior and knowledge sharing (Kim and Park, 2017). Individual innovation is manifested when employees are emotionally involved and motivated by their work because they experience satisfaction and enthusiasm. (Macey and Schneider, 2008).

Based on the results of hypothesis testing conducted, the result showed there is positive effect and significant between leader member exchange and innovative work behavior via work engagement. And the result of VAF Value showed that work engagement as a partial mediation. Employee who have high quality leader member exchange and have a high work engagement, then employees will bring up high innovative work behavior as well. Employee have a low quality leader member exchange and have a low work engagement, then the innovative work behavior of employees is also low.

The results of this study are in line with research conducted by previous researchers conducted by Argawal et al. (2012) which shows the results of leader member exchange has 
an positive effect on innovative work behavior of employees mediated by work engagement. When employees find their work meaningful and interesting, they will become enthusiastic to persevere in completing their work. Leaders have an important role in fostering subordinate work engagement (Argawal, et al., 2012). Leaders who support subordinates (professionally and emotionally) give them direction and information, and unleash hidden potential and foster willingness among subordinates to dedicate efforts and abilities to complete work assignments (Argawal, et al., 2012). Innovative behavior involves the creation of something new, this makes employees are required to concentrate and full of enthusiasm (vigor) in their work (Argawal, et al., 2012). In bringing out innovative work behavior, employees have metal resistance to stay focused and refrain from things that are not related to their work (Argawal, et al., 2012). Coginitive and emotional investment activities that are continuous, employees must understand the significance and pride of what they do and find the extra effort useful (Argawal, et al. 2012). When employees find their work meaningful and interesting, they will be enthusiastic and focused in their work, persisting to complete even the most difficult work (Argawal, et al., 2013). Feelings of pleasure at work trigger willingness to experiment, which leads to the creation of new ideas and new solutions (Argawal, et al., 2012). When employees feel energetic and happy in their work, employees are more likely to be involved in innovative processes using existing resources (Park, et al., 2013). With a supportive attitude from leader, this causes employees to feel that their work environment is safe for taking risks (Saeed, et al., 2018). Being in an encouraging work environment and having quality leader member exchange will facilitate employee innovation (Saeed, et al., 2018). When employees receive direct support and good relationships, they respond by dedicating efforts to complete tasks (Argawal, et al., 2012).

\section{CONSLUSION}

The findings indicated that the leader member exchange had a positive effect on the innovative work behavior, and work engagement had a positive effect on the innovative work behavior. Related to the mediating role, work engagement had a mediating role in the relationship between leader member exchange and innovative work behavior.

\section{REFERENCES}

1. Alsughayir, A. (2017). The effect of leader-member exchange on innovative work behavior in the Saudi hospitality. International Journal of Business and Management. 12(6). 189-195.

2. Anggita, V. (2019, 12 Agustus). Sektor Manufaktur Dorong Pertumbuhan Ekonomi. SWA [ONLINE]. Diakses pada tanggal 16 September 2019 dari https://swa.co.id/swa/trends/sektor-manufaktur-dorong-pertumbuhan-ekonomi.

3. Anshari, A., Brasit. N., Hamid, N. (2018). Pengaruh leader member exchange (LMX) organizational citizenship behavior (OCB) terhadap innovative work behavior (IWB) untuk meningkatkan kinerja organisasi (studi pada PT. Persero) Angkasa Pura I Bandara International Hasanuddin). Jurnal Bisnis, Manajemen dan Informatika 3 217-227.

4. Anwar, R., \& Niode, S.H.M. (2017). The Effects of Learning Organizations towards Employees' Innovative Behavior Mediated by Work Engagement (study in Indonesia). Advances in Intelligent Systems Research, volume 131 International Conference of Organizational Innovation (ICOI 2017)

5. Argawal, U.A., Datta, S. Blake-Beard, S. Bhargava, S. (2012). Linking LMX, innovative work behaviour and turnover intentions: The mediating role of work engagement Career Development International Vol. 17 No. 3, 2012, pp. 208-230.

6. Agarwal, U.A. (2014). Linking justice, trust and innovative work behaviour to work engagement. Personnel Review, Vol. 43 Iss 1 pp. 41-73.

7. BPS. (2019). Laporan Bulanan Data Sosial Ekonomi Januari 2019. Jakarta: Badan Pusat Statistik. 
8. Contreras, F., Espinosa, J.C., Dornberger, U., \& Acosta, Y.A.C. (2017). Leadership and employees' innovative work behavior: Test of a mediation and moderation model. Asian Social Science, 13(9),9-25.

9. De Jong, J. P. J., \& Den Hartog, D. N. (2007). How leader influence employees' innovative behavior. European Journal of Innovation. 10 (1) 41-64.

10. De Jong, J. P. J., \& Den Hartog, D. N. (2008). Innovative work behavior: Measurement and validation. EIM Research Reports.

11. De Jong, J. P. J., \& Den Hartog, D. N. (2010). Measuring innovative work behavior. Journal Creative and Innovative Behavior, 19 (1) 23-36.

12. Dhivya, A. S., \& Sripirabaa, B. (2015). The impact of leader member exchange on work engagement: An empirical study. International Journal of Management, 6(1), 139-150.

13. Global Innovation Index. (2018). The Global Innovation Index 2018: Energizing the World with Innovation. Cornell University, INSEAD, and the World Intellectual Property Organization.

14. Graen, G.B., Uhl-Bien, M. (1995). Relationship-based approach to leadership: Development of leader member exchange (LMX) theory of leadership over $25^{\text {th }}$ years: applying a multi-level multi-domain perspective. Leadership Wuarterly 6 (2) 219-247.

15. Hair, J., Hult, T., Ringle, C., \& Sarstedt, M. (2014). A Primer on Partial Least Squares Structural Equation Modeling (PLS-SEM). Thousand Oaks, CA Sage Publications Ltd.

16. June, S. \& Kheng, Y.K. (2014). Innovative Work Behavior (IWB) in the Knowledge Intensive Business Services (KIBS) Sector in Malaysia: The Effect of Leader-Member Exchange (LMX) and Social Capital (SC). Asian Social Science; Vol. 10, No. 2; 2014.

17. Kim, W. \& Park, J. (2018) Examining Structural Relationships between Work Engagement, Organizational Procedural Justice, Knowledge Sharing, and Innovative Work Behavior for Sustainable Organizations. Sustainability 2017, 9, 205.

18. Liden, R.C. \& Maslyn, J.M. (1998). Multidimensional of leader-member exchange an empirical assessment through scale development. Journal of Management 24 (1) $42-72$

19. Macey, W. H., \& Schneider, B. (2008). The meaning of employee engagement. Industrial and Organizational Psychology, 1(1), 3-30.

20. Park, Y.K., Song, J.H., Yoon, S.W., Kim, J. (2013) Learning Organization and innovative behavior the mediating effect of engagement. European Journal of Training and Development Vol. 38 No. 1/2, 2014 pp. 75-94.

21. Schaufeli, W. B., Salanova, M., González-Romá, V., \& Bakker, A. B. (2002). Measurement of engagement and burnout: A two sample confirmatory factor analytic approach. Journal of Happiness Studies, 3, 71-92.

22. Schaufeli W.B. \& Bakker, A. (2004). Utrecht work engagement scale. Premilinary Manual Version 1.1. Ocupational Health Psychology. Timisoara: Utrecht University.

23. Tanskanen, J., Makela, L., Viitala, R. (2018). Linking Managerial Coaching and LeaderMember Exchange on Work Engagement and Performance. J Happiness Stud (2019) 20:1217-1240.

24. Volmer, J., Spurk, D. and Niessen, C. (2012), "Leader-member exchange (LMX), job autonomy, and creative work involvement", The Leadership Quarterly, Vol. 23 No. 3, pp. 456-465.

25. Wang, X., Fang, Y., Qureshi., Janssen, O. (2015). Understanding employee innovative behavior: Integrating the social network and leader-member exchange perspectives. Journal of Organizational Behavior, J. Organiz. Behav. 